\title{
Is there a Future for Haematopoietic Cell Transplants?
}

\author{
Robert P. Gale \\ Haematology Research Centre, Department of Immunology and Inflammation Imperial College, London, UK \\ Robert Peter Gale MD, PhD, DSc (hc), FACP, FRCPI (hon), \\ Phone: +1-908-656-0484 \\ FRSM, Haematology Research Centre, Department \\ of Immunology and Inflammation Imperial College, \\ Fax: +1-310-388-1320 \\ E-mail: robertpetergale@alumni.ucla.edu
}

London, UK

Citation: Gale RP. Is there a Future for Haematopoietic Cell Transplants? Cell Ther Transplant 2020; 9(4): 6-10.

\section{Summary}

Recent advances in anti-cancer chemotherapy and in targeted and immune therapies raise the question whether there is a future for haematopoietic cell transplants. I discuss their importance but in the end the magnitude of these improvements is modest. I point out the efficacy of immune therapy is predominately restricted to B-cell cancers and that many if not most successful immune therapy recipients eventually receive an allogeneic haematopoietic cell transplant, especially those with acute lymphoblastic leukaemia (ALL). I also discuss most allotransplants are done for cancers not treated with current immune therapy. Randomized trials show an autotransplant is better than new drugs in young persons with plasma cell myeloma. Considerable data indicate much of the efficacy of allotransplants results from a non-cancer-specific allogeneic effect not expected to operate with current immune therapies. Lastly, I discuss a role for donor-derived chimeric antigen receptor (CAR)-T-cells in persons relapsing after an allotransplant for B-cell cancers. The sum of these considerations suggest an ongoing role for haematopoietic cell transplants in diverse settings.

\section{Keywords}

Hematopoietic stem cell transplantation, targeted drugs, immune therapy, (CAR)-T cells, efficiency.
This paper is based on the lecture held at the R. Gorbacheva Memorial Meeting in Hematopoietic Stem Cell Transplantation and Gene Therapy (Sept 19, 2020, St. Petersburg, Russia)

\section{Background}

Haematopoietic cell transplants are increasingly done to treat blood and bone marrow cancers, bone marrow failure and genetic disorders. In the US there were about 14,000 autotransplants and 9,000 allotransplants in 2018. Global autotransplants in 2019 were about 28,000 and allotransplants, about 17,000 with a total of about 45,000 . These rates are expected to increase. In the US most autotransplants are for plasma cell myeloma (PCM) and non-Hodgkin lymphoma (NHL) whereas most allotransplants are for acute myeloid leukaemia (AML) and myelodysplastic syndromes (MDS). Relatively few allotransplants were done for acute lymphoblastic leukaemia (ALL) or myelo-proliferative neoplasms
(MPNs; Table 1). This distribution is important as most immune therapies are for cancers not currently treated with haematopoietic cell transplants as I discuss below.

\section{Table 1. Indications for haematopoietic cell transplants in the US 2018 (https://www.cibmtr.org/ReferenceCenter/ SlidesReports/SummarySlides/pages/index.aspx)}

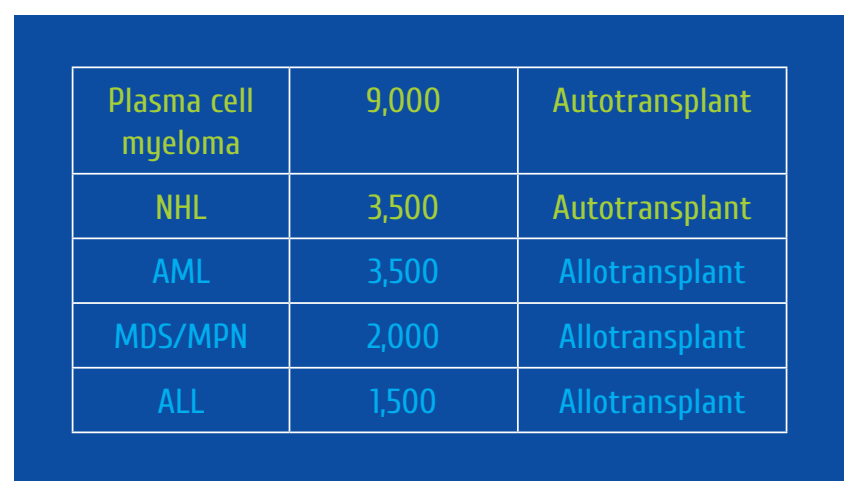




\section{Discussion}

Recent interventions which might compete with haematopoietic cell transplants include new anti-cancer chemotherapy and targeted and immune therapies. Several new drugs used to treat blood and bone marrow cancers are listed in Table 2.

Table 2. Some new drugs for blood and bone marrow cancers

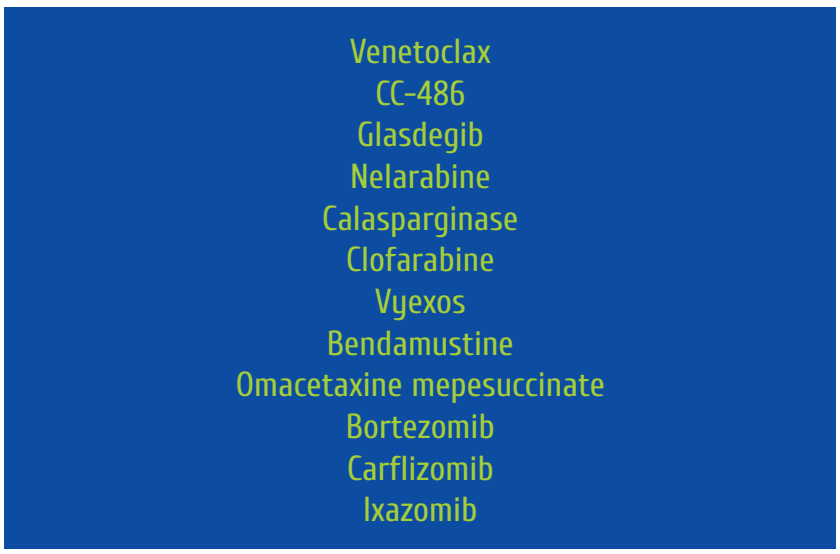

Although progress in developing new drugs is encouraging the magnitude of benefit with several of these drugs is modest. An example of the impact of azacitidine and venetoclax in newly diagnosed persons with AML judged inappropriate to receive intensive chemotherapy is shown in Figure 1. Although adding venetoclax to azacitidine significantly improved survival, $65 \%$ of subjects died by 2.5 years.

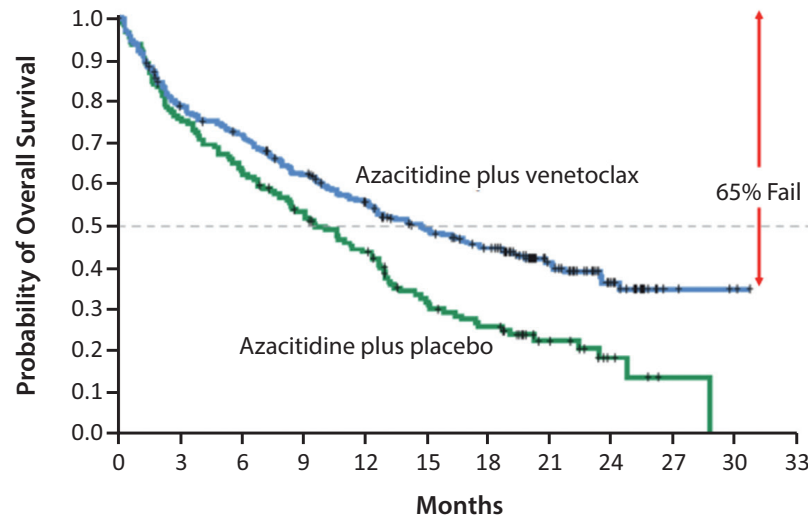

Figure 1. Results of a randomized trial of azacitidine with or without venetoclax in persons with newly diagnosed $A M L$ judged inappropriate to receive intensive chemotherapy [1]

Table 3 shows the 5-year survivals of persons with AML and PCM treated in 1999-2003, and treated 2010-2016. These data indicate only a modest improvement with about 70 percent of persons with AML and 45 percent of those with PCM dying before 5 years.

Examples of targeted therapies for myeloid cancers, especially AML are shown in Table 4 along with the target gene.
Table 3. 5-year survivals of persons with AML and PCM by therapy interval (https://seer.cancer.gov/)

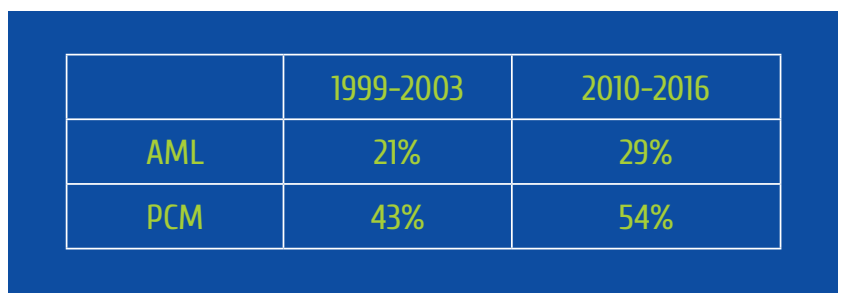

Table 4. Some targeted therapies for myeloid cancers

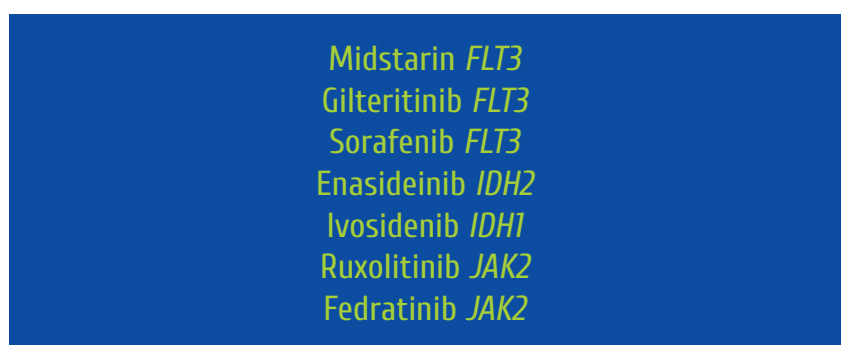

An example of the impact of targeted FLT3 mutation therapy in AML is shown in Fig. 2 [2]. Although adding midostaurin to cytarabine and daunorubicin improves survival, 55 percent of subjects died by 5 years and many survivors also received an allotransplant in $1^{\text {st }}$ remission. These data indicate a modest impact of targeted therapy in AML.

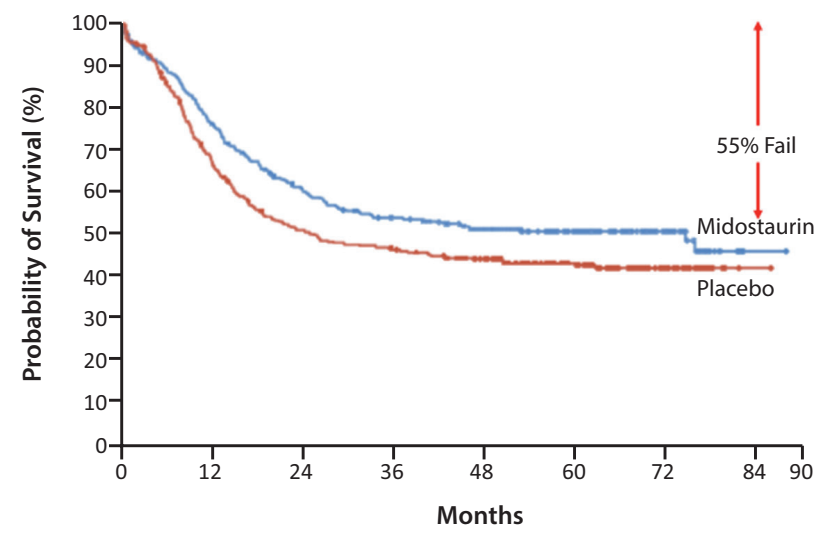

Figure 2. Cytarabine and daunorubicin with or without midostaurin in newly-diagnosed AML [2]

Fig. 3 displays the estimated impact of targeted therapies on survival of persons with acute myeloblastic leukemia (AML) [3]. It seems only about 10 percent of people will benefit.

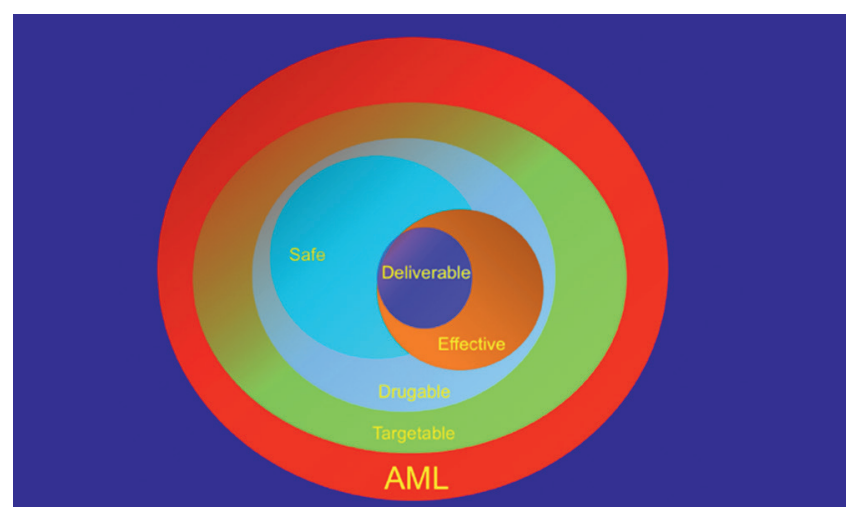

Figure 3. Estimated benefit of targeted therapy in AML [3] 
Immune therapy is another new therapy of blood and bone marrow cancers. Some examples are displayed in Table 5.

Table 5. Some examples of immune therapies in blood and bone marrow cancers

\section{Immune Therapy Breakthroughs}

Monoclonal antibodies Rixtuxumab CD20,

Daratumumab BCMA

Antibody-drug conjugates Brentuximab

vedotin $\mathrm{CD} 30$

Bi-specific (BiTE) antibodies Blinotumomab

CD20/CD30

CAR-T-cells CD19, CD20, BCMA

Checkpoint inhibitors PD-1, PD-1L, CTLA-4

However, these therapies are effective only in B-cell cancers and are lineage- but not cancer-specific (Fig. 4). Other than gemtuzumab ozogamicin, an anti-CD33 monoclonal antibody, there is no proved safe and effective therapy of myeloid cancers.

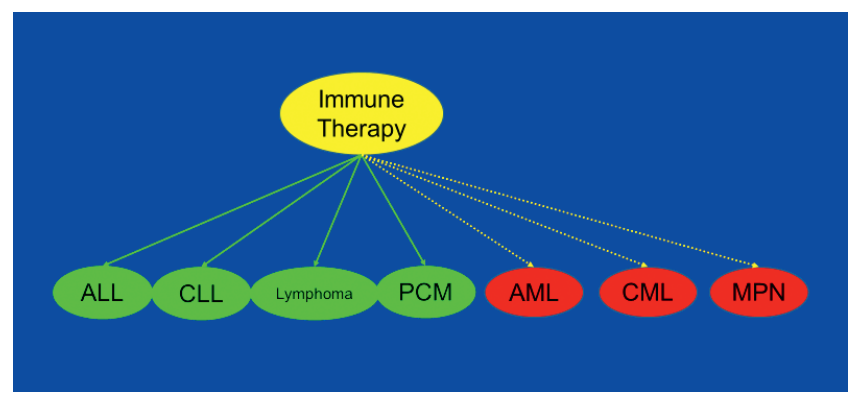

Figure 4. Scheme of immune therapy of lymphoid and myeloid cancers

CAR-T-cells are an important advance in therapy of lymphoid cancers with high response rates. However, often responses are not sustained unless a subsequent allogeneic haematopoietic cell transplant is done. An example of event-free survival (EFS) in children and young adults with advanced ALL is shown in Figure 5 with a failure rate of 40 percent at 1.5 years in complete responders [4].

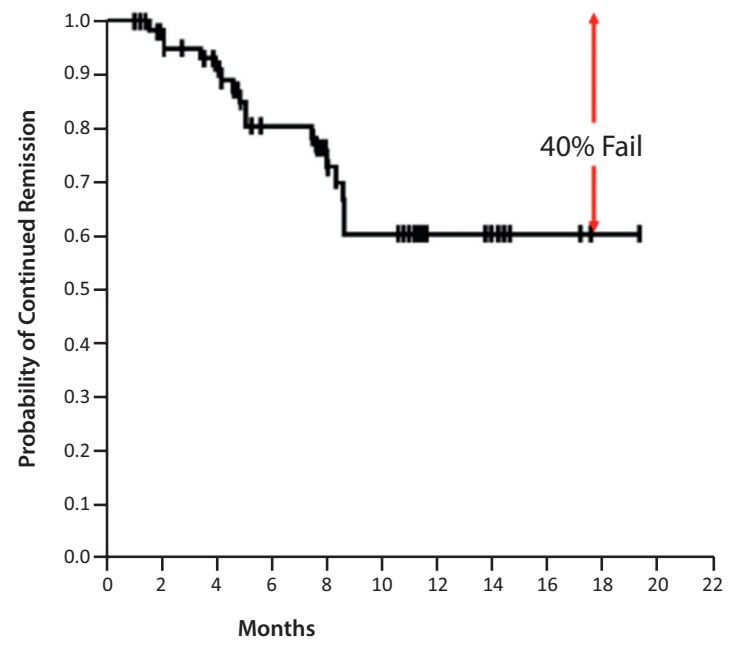

Figure 5. Event-free survival in children and young adults with advanced ALL after successful CAR-T-cell therapy [4]
Similarly, there are high rates of therapy-failure after successful CAR-T-cell therapy of diffuse large B-cell (DLBCL; Figure 6), follicular (FL) and marginal zone lymphomas (MZL; Fig. 7). [5] (https://ascopubs.org/doi/abs/10.1200/ JCO.2020.38.15_suppl.8008).

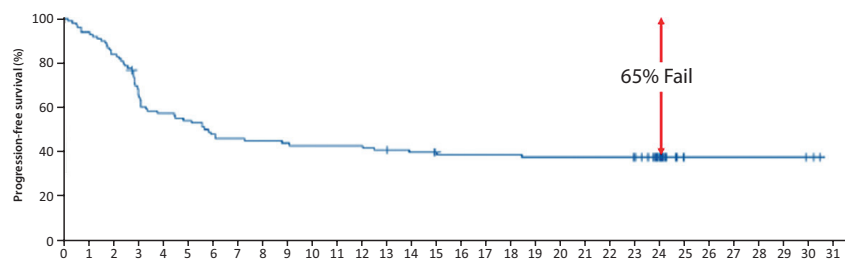

Figure 6. PFS after successful CAR-T-cell therapy of DLBCL [5]

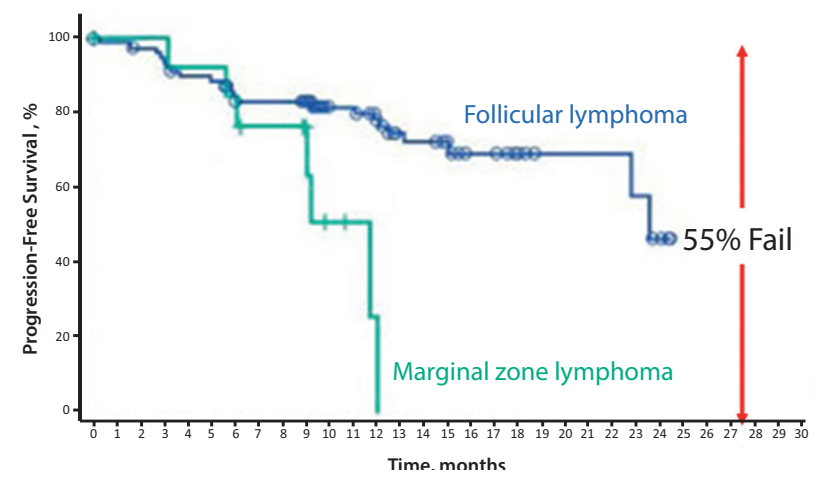

Figure 7. PFS after successful CAR-T-cell therapy of FL and MZL (https://ascopubs.org/doi/abs/10.1200/ JC0.2020.38.15_suppl.8008)

The argument CAR-T-cell therapy serves predominately as a bridge to an allotransplant is unconvincing as there are no strong data survival of persons with ALL transplanted in $2^{\text {nd }}$ remission are better than those transplanted in relapse when all subjects are accounted for. Consequently, the best approach to someone responding to CAR-T-cell therapy is controversial. It may be reasonable to consider an allotransplant in persons with ALL and in those with MZL after responding to CAR-T-cell therapy, but wait for therapy failure in those with DLBCL and FL (Fig. 8).

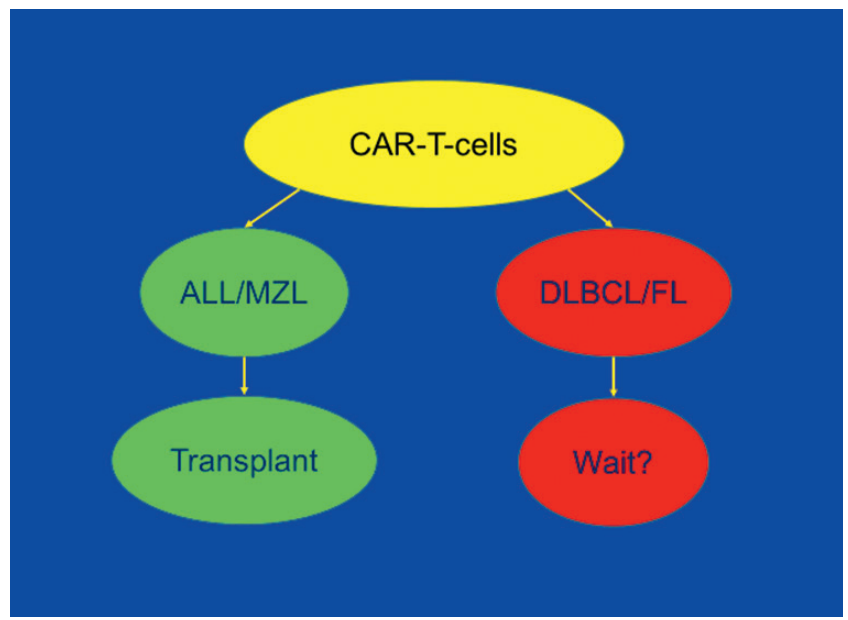

Figure 8. Possible roles for allotransplants is persons receiving CAR-T-cell therapy 
It is also important to recall much of the efficacy of allotransplants results from an allogeneic anti-cancer effect so far difficult to distinguish from graft-versus-host disease (GvHD) [6]. These data are displayed in Fig. 9. For example, whether there is a specific anti-leukaemia effect is controversial, as reviewed in [7].

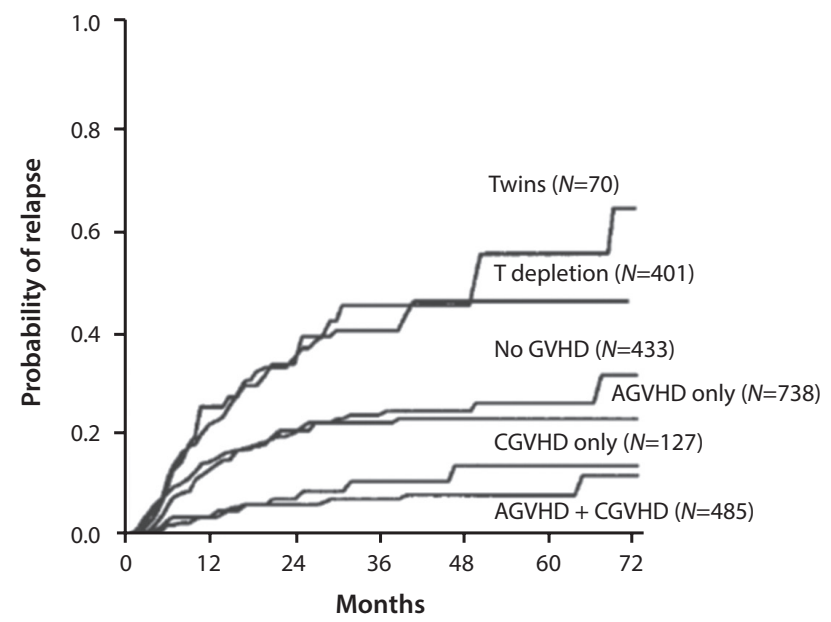

Figure 9. Actuarial probability of relapse in recipients of bone marrow transplants for AML [6]

Some data suggest the potential use of donor-derived CART-cells in persons relapsing after an allotransplant for B-cell cancers [8].

\section{Conclusion}

Advances in treating ALL, AML, lymphomas and PCM are important and exciting but the magnitude of benefit is modest and few people are cured. Many persons with immune therapy successes go on to receive an allotransplant. Most cancers where immune therapy is effective are B-cell cancers whereas most allotransplants are done for myeloid cancers. Moreover, these immune therapies are lineage-, not cancer-specific and lack the allogeneic anti-cancer effect associated with allotransplants. In young persons with PCM, autotransplants are better than new drugs in randomized clinical trials. CAR-T-cell therapy of B-cell cancers is effective but mostly not a cure. Donor CAR-T-cells are a promising in persons relapsing after an allogeneic haematopoietic cell transplant. Transplants will remain an important therapy in the immediate future. Put in terms of food, although there is nouvelle cuisine Boef Stroganoff remains a classic and my $1^{\text {st }}$ dinner choice at Chekhov restaurant in Petersburg.

\section{Acknowledgement}

Supported by the National Institute of Health Research (NIHR) Biomedical Research Centre funding scheme. Prof. Elena Parovichnikova and Drs. Kristina Zakurdaeva and Saida Kadyrova provided expert advice on Boef Stroganoff and Dr. Ivan Moiseev and the late Prof. Boris Afanasyev introduced me to Chekhov restaurant. My preference is for Boef Stroganoff with kasha. Bon Appetit.

\section{Conflict of interest}

RPG is a consultant to BeiGene Ltd., Fusion Pharma LLC, LaJolla NanoMedical Inc., Mingsight Parmaceuticals Inc. and CStone Pharmaceuticals; advisor to Antegene Biotech LLC, Medical Director, FFF Enterprises Inc.; partner, AZAC Inc.; Board of Directors, Russian Foundation for Cancer Research Support; and Scientific Advisory Board: StemRad Ltd.

\section{References}

1. DiNarco CD, Jonas BA, Pullarkat V, Thirman MJ, Garcia JS, Wei AH, et al. Azacitidine and Venetoclax in previously untreated acute myeloid leukemia. N Engl J Med. 2020;383:617-629.

2. Stone RM, Mandrekar SJ, Sanford BL, Lauman K, Geyer S, et al. Midostaurin plus chemotherapy for acute myeloid leukemia with FLT3 mutation. N Engl J Med. 2017;377:454-464.

3. Prasad V, Gale RP. Precision medicine in acute myeloid leukemia: Hope, hype or both? Leuk Res. 2016;48:73-77.

4. Maude SL, Laetsch TW, Buechner J, Rives S, Boyer M, Bittencourt $\mathrm{H}$, et al. Tisagenlecleucel in children and young adults with B-Cell lymphoblastic leukemia. N Enl J Med. 2018;378:439-448.

5. Locke FL, Ghobadi A, Jacobson CA, et al. Long-term safety and activity of axicabtagene ciloleucel in refractory large B-cell lymphoma (ZUMA-1): a single-arm, multicentre, phase 1-2 trial. Lancet Oncol 2019; 20: 31-42.

6. Horowitz MM, Gale RP, Sondel PM, Goldman JM, Kersey J, Kolb HJ, et al. Graft-versus-leukemia reactions after bone marrow transplantation. Blood. 1990;75:555-562.

7. Gale RP, Fuchs EJ. Is there really a specific graft-versus-leukaemia effect? Bone Marrow Transplant. 2016;51:1413-1415.

8. Zhang C, Wang XQ, Zhang RL, Liu F, Wang Y, Yan ZL, et al. Donor-derived CD19 CAR-T-cell therapy of relapse of CD 19-positive B-ALL posttransplant. Leukemia.2020; In Press. 


\section{Есть ли будущее у трансплантации гемопоэтических клеток?}

\section{Роберт П. Гэйл}

Центр гематологии, Департамент иммунологии и воспаления, Имперский коледж Лондон, Великобритания

\section{Резюме}

Нынешние успехи противоопухолевой терапии, таргетной и иммунотерапии подримают вопрос о том, есть ли будущее у трансплантации гемопоэтическитх клеток (ТГСК). Я обсуждаю важность этого, но, в итоге, масштаб этих усовершенствований пока скромен.

Я подчеркиваю, что эффективность иммунной терапии ограничена, преимущественно, В-клеточными опухолями, и что у многих, если не большинства больных, успешно леченных посредством иммунотерапии, может выполняться аллогенная ТГСК, особенно при остром лимфобластном лейкозе (ОЛЛ).

Я также обсуждаю то, что большинство аллотрансплантаций проводятся по поводу злокачественных заболеваний, которые не лечатся существующей иммунотерапией.

Рандомизированные испытания показывают, что аутотрансплантация - лучше, чем новые препараты при лечении молодых пациентов с плазмаклеточной миеломой. Значительное число данных указывает на то, что эффективность аллотрансплантации обусловлена не опухольспецифическими аллогенными эффектами, которые, очевидно, не связаны с существующей иммунотерапией.

Наконец, я обсуждаю роль применения Т-клеток с донорским химерным антигенным рецептором (CAR-T) у лиц, рецидивирующих после алло-ТГСК при В-клеточных опухолях. В итоге можно предполагать и в последующем значительную роль трансплантации гемопоэтических клеток в различных клинических ситуациях.

\section{Ключевые слова}

Трансплантация гемопоэтических стволовых клеток, таргетные препараты, иммунная терапия, CAR-T клетки, эффективность. 